\title{
Detection of Zoonotic Bartonella Pathogens in Rabbit Fleas, Colorado, USA
}

\author{
Shingo Sato, ${ }^{1}$ R. Jory Brinkerhoff, ${ }^{1}$ Erin Hollis, Shunta Funada, Avery B. Shannon, Soichi Maruyama
}

We detected 3 Bartonella species in wild rabbit fleas from Colorado, USA: B. vinsonii subsp. berkhoffii $(\mathrm{n}=16), B$. alsatica $(n=5)$, and $B$. rochalimae $(n=1)$. Our results support the establishment of the zoonotic agent $B$. alsatica in North America.

W ild lagomorphs (rabbits, hares, and pikas) are known or potential reservoirs for a number of zoonotic agents, including tularemia (Francisella tularensis), plague (Yersinia pestis), pasteurellosis (Pasteurella multocida), ringworm (Trichophyton spp.), and cryptosporidiosis (Cryptosporidium cuniculus) (1). In 1999, a novel Bartonella species, B. alsatica, was isolated from the blood of wild rabbits (Oryctolagus cuniculus) in eastern France (2). B. alsatica was later identified as a causative agent of lymphadenitis (3) and endocarditis $(4,5)$ in humans. A case of prosthetic vascular graft infection caused by B. alsatica was reported in 2019 (6).

The geographic distribution of $B$. alsatica is poorly understood, as is its mode of transmission, although vector-mediated transmission was suggested upon initial characterization of this agent (2). B. alsatica DNA has been detected in fleas collected from Bartonella-infected wild rabbits in France (7) and Spain $(8,9)$, suggesting the potential for fleaborne B. alsatica transmission. Our goal was to describe associations between rabbit-associated Bartonella and potential flea vectors in the United States to gain insights into transmission of fleaborne zoonoses.

\section{The Study}

We collected fleas from live-trapped desert cottontail rabbits (Sylvilagus audubonii) in June and July 2005

Author affiliations: Nihon University College of Bioresource Sciences, Fujisawa, Japan (S. Sato, S. Funada, S. Maruyama); University of Richmond, Richmond, Virginia, USA

(R.J. Brinkerhoff, E. Hollis, A.B. Shannon); University of KwaZulu-Natal, Pietermaritzburg, South Africa (R.J. Brinkerhoff) from 8 sites in Boulder County, Colorado, USA (10). We identified fleas to species by light microscopy using dichotomous keys (10) and then stored them in 96-well tissue culture plates at $-20^{\circ} \mathrm{C}$, except for representatives of each species that were removed and submitted to the Centers for Disease Control and Prevention (Fort Collins, CO, USA). In 2015, we extracted DNA from individual fleas using commercial DNA extraction kits (Blood and Tissue Kit; Macherey-Nagel, Inc., https://www.mn-net.com), with aliquots of extracted DNA maintained at the University of Richmond (Richmond, VA, USA), and secondary aliquots sent to the Laboratory of Veterinary Public Health, Nihon University College of Bioresource Sciences (Fujisawa, Japan). Both laboratories screened samples for Bartonella infection by conventional PCR targeting part of the ssrA gene; primers used were ssrA-F (5'-GCTATGGTAATAAATGGACAATGAAATAA-3') and ssrA-R (5'-GCTTCTGTTGCCAGGTG-3'). The targeted gene was selected because of the robustness of the PCR assay and the ability of the locus to segregate Bartonella at the species level (11). Nihon University College of Bioresource Sciences also used real-time PCR targeting the ssrA gene to confirm Bartonella species for those samples. This PCR used a genus-specific TaqMan probe, 6-carboxyfluorescein (FAM)-labeled probe (5'-FAM-ACCCCGCTTAAACCTGCGACG-3'BHQ1, where BHQ is black hole quencher); primers were the same as for conventional PCR. Samples that tested positive for Bartonella DNA by real-time PCR and for which unambiguous sequence data were collected in both laboratories from the target locus (ssrA) were reported as Bartonella positive. We sequenced all amplicons (301 bp) from conventional PCR and aligned them with Bartonella type strains and then subjected them to phylogenetic analysis using MEGA 7.0 (https:/ / www.megasoftware.net).

We collected 141 fleas from 14 desert cottontail rabbits (average fleas per parasitized host 14.3,

\footnotetext{
${ }^{1}$ These authors contributed equally to this article.
} 
Table 1. Fleas collected from desert cottontail rabbits (Sylvilagus audubonii) in Boulder County, Colorado, USA, and analyzed for presence of Bartonella

\begin{tabular}{|c|c|c|c|c|c|}
\hline \multirow{2}{*}{$\begin{array}{l}\text { Rabbit ID } \\
\text { no. }\end{array}$} & \multirow[b]{2}{*}{ Sampling date } & \multirow{2}{*}{$\begin{array}{l}\text { No. fleas collected } \\
\text { (no. tested) }\end{array}$} & \multicolumn{2}{|c|}{ No. Bartonella-positive fleas (no. tested), \% positive } & \multirow{2}{*}{$\begin{array}{c}\text { Bartonella prevalence } \\
\text { in fleas, } \%\end{array}$} \\
\hline & & & Cediopsylla inaequalis & Euhoplopsyllus glacialis & \\
\hline 305 & 2005 Jul 14 & $2(2)$ & 0 & $1(2), 50$ & 50.0 \\
\hline 633 & 2005 Jul 18 & $17(17)$ & $0(4), 0$ & $11(13), 85$ & 64.7 \\
\hline 673 & 2005 Jul 21 & $4(2)$ & 0,0 & $1(2), 50$ & 50.0 \\
\hline 674 & 2005 Jul 21 & $8(7)$ & 0,0 & $2(7), 29$ & 28.6 \\
\hline 794 & 2005 Jul 28 & $4(3)$ & 0,0 & $0(3), 0$ & 0 \\
\hline
\end{tabular}

range 1-54) in the summer of 2005. Of these fleas, 105 (81 Euhoplopsyllus glacialis and 24 Cediopsylla inaequalis) collected from 7 rabbits sampled at 4 sites (Table 1; specific site locations in 10) were available for molecular screening for Bartonella. The remaining 36 fleas were processed for Yesinia pestis surveillance in a separate project (R.J. Brinkerhoff et al., unpub. data) and were not available for Bartonella testing.

We detected Bartonella DNA in $2(8.3 \%)$ C. inaequalis fleas collected from 1 rabbit (ID no. 522) and 21 (25.9\%) E. glacialis fleas collected from 5 rabbits (ID nos. 305, 522, 633, 673, and 674) (Table 1). All nucleotide sequences matched closely to 3 zoonotic Bartonella species, B. alsatica, B. vinsonii subsp. berkhoffii, and $B$. rochalimae (Table 2 ), and clustered phylogenetically with reference sequences of the type strains with high bootstrap support (Figure). The representative sequences of the 3 Bartonella species were registered in International Nucleotide Sequence Database Collaboration with accession nos. PS522-c9 (GenBank accession no. MN654366), PS674-e5 (GenBank accession no. MN654366), and PS674-e6 (GenBank accession no. MN654366). All 3 rabbits (ID nos. $522,633,674)$ from which $>1$ flea was PCR-positive and available for sequencing produced multiple Bartonella species (Table 2).

\section{Conclusions}

We detected DNA of 3 zoonotic Bartonella species among the 105 rabbit fleas we tested for this study; overall Bartonella prevalence in fleas was $21.9 \%$ (23/105), which is comparable to previous prevalence estimates from rabbit fleas in Europe $(7,9)$. This study had several noteworthy findings: B. alsatica DNA was detected in North America, and carnivore-associated Bartonella species occurred in rabbit fleas. These findings highlight the complexity of pathogen-vector-host associations and demonstrate why vector ecology is necessary for elucidating the evolution and enzootic transmission of vectorborne pathogens. Since B. alsatica was described in 1999 (2), its DNA has been detected not only in European rabbits (Oryctolagus cuniculus) in Spain (8) but also in rabbit fleas (Spilopsyllus cuniculi and Xenopsylla cunicularis) collected in France (7) and Spain (9) and has been associated with human disease in France (3-6). In 2019, detection of B. alsatica DNA was reported in cat fleas (Ctenocephalides felis) infesting cats and dogs in the United Kingdom (12).

A recent study reported fts $Z$ and $n u o G$ sequences with $\approx 95 \%$ similarity to $B$. alsatica from the spleens of spiny rats (Thrichomys fosteri) in Brazil (13), the only previous published report of $B$. alsatica in the Americas. The B. alsatica sequences in our study were

Table 2. Bartonella sequence identities for ssrA amplicons amplified from Cediopsylla inaequalis and Euhoplopsyllus glacialis fleas collected from 5 desert cottontail rabbits (Sylvilagus audubonii) in Boulder County, Colorado, USA*

\begin{tabular}{lccc}
\hline Host no. & Flea nos. & Flea species & Closest Bartonella strains/sequence homologies/\% (GenBank \\
accession no.)
\end{tabular}




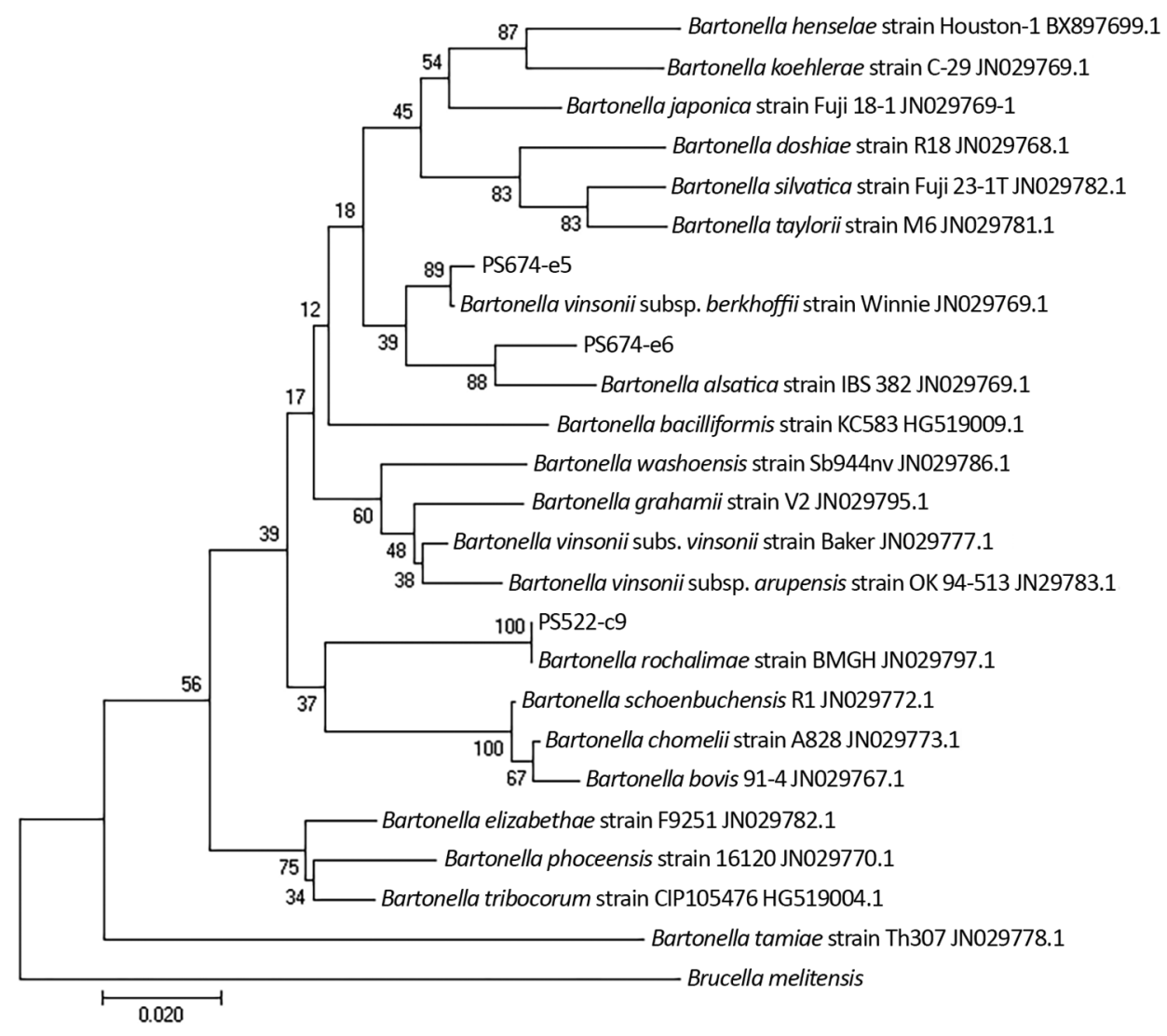

Figure. Phylogenetic relationships of Bartonella ssrA sequences detected in study of zoonotic Bartonella in rabbit fleas, Colorado, USA, compared with reference sequences. This tree was generated based on $253 \mathrm{bp}$ by maximum likelihood and 1,000 bootstrap replicates using the Kimura 2-parameter evolutionary model with gamma-distributed rates among sites. Sample numbers are found in Table 2. GenBank accession numbers are indicated. Scale bar indicates nucleotide substitutions per site. more similar to the B. alsatica type strain than were the putative $B$. alsatica sequences detected in Brazil. However, the B. alsatica sequences in our study were not identical to the type strain, suggesting that divergent $B$. alsatica strains may be circulating in the Americas. Further sampling of lagomorphs and their ectoparasites throughout North and South America is necessary to determine the geographic extent of $B$. alsatica, as well as its genotypic variation and evolutionary history.

We can conclude that both $C$. inaequalis and $E$. glacialis fleas are able to acquire Bartonella DNA and that blood-feeding is a likely mode of Bartonella acquisition, based on the observation that multiple fleas from the same host tested positive for Bartonella DNA. The detection of carnivore-associated Bartonella species in rabbit fleas was unexpected; typical reservoirs for B. rochalimae and B. v. subsp. berkhoffii are wild carnivores such as coyotes, foxes, raccoons, and skunks. However, B. rochalimae or B. rochalimae-like bacteria were found in the blood of brown rats (Rattus norvegicus) captured in Taiwan and in California, USA (14). Thus, B. rochalimae might have the potential to infect rodents as well as carnivores. Both rabbit flea species sampled in this study have been recovered from wild carnivore species in our study system and thus could serve as bridge vectors between carnivores and rabbits (10). In Europe, rabbit fleas have also been collected from carnivores (15), suggesting potential lagomorph-carnivore B. alsatica transmission in other systems as well.

Yersinia pestis, another fleaborne zoonotic agent that periodically causes epizootic events in our system (10), may spill over into amplifying hosts from putative reservoirs (mammalian, flea, or both) or from environmental sources. Flea and Bartonella (Table 2) exchange between lagomorphs and carnivores suggests that $Y$. pestis could also jump among these groups of mammals. Moreover, desert cottontails co-occur with black-tailed prairie dogs (Cynomys ludovicianus), a species associated with epizootic $Y$. pestis emergence, and flea exchange between desert cottontails and prairie dogs has been described (10). Given our findings, it is apparent that desert cottontail rabbits are associated with multiple zoonotic Bartonella species, including $B$. alsatica, which had not been previously recorded in North America, and that wild lagomorphs may contribute to the maintenance and transmission of several vectorborne zoonoses. 
All wildlife sampling was conducted with approval from the Institutional Animal Care and Use Committee at the University of Colorado-Boulder.

Funding for this project was provided in part by a Weinstein grant from the University of Richmond to S.S. and R.J.B., by a Fulbright Scholar Award to R.J.B., and by National Science Foundation grant no. EF0224328. This project was also supported by a University of Richmond Arts and Sciences Summer Fellowship to A.B.S. Additional funding was provided by Nihon University College of Bioresource Sciences.

\section{About the Author}

Dr. Sato is an assistant professor in the Department of Veterinary Medicine, College of Bioresource Sciences, Nihon University, Fujisawa, Japan. His primary research interests are the epidemiology of bartonellosis, bacterial ecology in wildlife, and control of bacterial zoonoses.

\section{References}

1. Hill WA, Brown JP. Zoonoses of rabbits and rodents. Vet Clin North Am Exot Anim Pract. 2011;14:519-31, vii. https://doi.org/10.1016/j.cvex.2011.05.009

2. Heller R, Kubina M, Mariet P, Riegel P, Delacour G, Dehio C, et al. Bartonella alsatica sp. nov., a new Bartonella species isolated from the blood of wild rabbits. Int J Syst Bacteriol. 1999;49:283-8. https://doi.org/10.1099/00207713-49-1-283

3. Angelakis E, Lepidi H, Canel A, Rispal P, Perraudeau F, Barre I, et al. Human case of Bartonella alsatica lymphadenitis. Emerg Infect Dis. 2008;14:1951-3. https://doi.org/10.3201/ eid1412.080757

4. Raoult D, Roblot F, Rolain JM, Besnier JM, Loulergue J, Bastides F, et al. First isolation of Bartonella alsatica from a valve of a patient with endocarditis. J Clin Microbiol. 2006;44:278-9. https://doi.org/10.1128/JCM.44.1.278-279.2006

5. Jeanclaude D, Godmer P, Leveiller D, Pouedras P, Fournier PE, Raoult D, et al. Bartonella alsatica endocarditis in a French patient in close contact with rabbits. Clin Microbiol Infect. 2009;15(Suppl 2):110-1. https:/ / doi.org/ 10.1111/j.1469-0691.2008.02187.x
6. Puges M, Ménard A, Berard X, Geneviève M, Pinaquy JB, Edouard S, et al. An unexpected case of Bartonella alsatica prosthetic vascular graft infection. Infect Drug Resist. 2019;12:2453-6. https://doi.org/10.2147/IDR.S206805

7. Kernif T, Parola P, Ricci JC, Raoult D, Rolain JM. Molecular detection of Bartonella alsatica in rabbit fleas, France. Emerg Infect Dis. 2010;16:2013-4. https:/ / doi.org/ 10.3201/eid1612.100696

8. Márquez FJ. Molecular detection of Bartonella alsatica in European wild rabbits (Oryctolagus cuniculus) in Andalusia (Spain). Vector Borne Zoonotic Dis. 2010;10:731-4. https:// doi.org/10.1089/vbz.2009.0135

9. Márquez FJ. Detection of Bartonella alsatica in European wild rabbit and their fleas (Spilopsyllus cuniculi and Xenopsylla cunicularis) in Spain. Parasit Vectors. 2015;8:56. https:/ / doi.org/10.1186/s13071-015-0664-1

10. Brinkerhoff RJ. Mammal and flea occurrence in association with black-tailed prairie dog (Cynomys ludovicianus) colonies: implications for interspecific plague transmission [dissertation]. Boulder (CO): University of Colorado; 2008.

11. Diaz MH, Bai Y, Malania L, Winchell JM, Kosoy MY. Development of a novel genus-specific real-time PCR assay for detection and differentiation of Bartonella species and genotypes. J Clin Microbiol. 2012;50:1645-9. https://doi.org/ 10.1128/JCM.06621-11

12. Abdullah S, Helps C, Tasker S, Newbury H, Wall R. Pathogens in fleas collected from cats and dogs: distribution and prevalence in the UK. Parasit Vectors. 2019;12:71. https:/ / doi.org/ 10.1186/s13071-019-3326-x

13. de Sousa KCM, do Amaral RB, Herrera HM, Santos FM, Macedo GC, de Andrade Pinto PCE, et al. Genetic diversity of Bartonella spp. in wild mammals and ectoparasites in Brazilian Pantanal. Microb Ecol. 2018;76:544-54. https:/ / doi.org/10.1007/s00248-017-1138-0

14. Gundi VA, Billeter SA, Rood MP, Kosoy MY. Bartonella spp. in rats and zoonoses, Los Angeles, California, USA. Emerg Infect Dis. 2012;18:631-3. https:/ / doi.org/10.3201/ eid1804.110816

15. Márquez FJ, Millán J, Rodríguez-Liébana JJ, García-Egea I, Muniain MA. Detection and identification of Bartonella sp. in fleas from carnivorous mammals in Andalusia, Spain. Med Vet Entomol. 2009;23:393-8. https://doi.org/10.1111/ j.1365-2915.2009.00830.x

Address for correspondence: R. Jory Brinkerhoff, University of Richmond Department of Biology, 28 Westhampton Way, Richmond, VA 23173, USA; email: jbrinker@richmond.edu 